Instead of an era of immobility followed by gentle movements, as described by Mr. Busk, I suggest that the features of the Rift Zone are due very largely to prolonged but intermittent continental uplift and consequent erosion, interrupted by two main periods of faulting - the post-Karroo and the Rift.

Great isolated mountains such as Ruwenzori and certain lesser heights are to be regarded in part, I suggest, as the cores of grea residuals due to this long-continued uplift, and bounded locally by ancient faults.

Finally, in the north-eastern part of the Northern Frontier District, Mr. Busk has referred to certain isolated hills as horsts that rose above the Jurassic sea, and he quotes them as evidence for Jurassic block-faulting in this area. These views are based on the assumption that the red sandstone hills in question are older than the surrounding Jurassic limestones ; but actually the red sandstones (Marahan Sandstones) succeed the limestones by way of a well-defined transitional zone of alternating limestones and sandstones, as is clearly displayed in excellent sections along the westward-facing scarps. There may be faulting in the area, but the topography is due essentially to normal dip and strike structures in gentlyfolded sediments and to the presence of high, steep-sided outliers of the resistant Marahan Sandstones resting on the limestones.

Geological Survey Department,

F. DIXEY.

KADUNA JUNCTION, NigERIA.

7th May, 1945.

\title{
A JURASSIC OUTCROP IN THE JORDAN VALLEY
}

SIRs,--In your issue of March-April, M. Avnimelech described an interesting discovery of Jurassic rocks from a new locality in the Jordan Valley, but I should like to register disagreement with the deductions which he draws therefrom. He suggests that the incompleteness of the Upper Jurassic succession in the Yabbok area may be due to movements in Callovian times forming a local domal uplift, whereas I would prefer a more regional explanation. A short distance further south marine Triassic beds are present in Wadi Hesban and Wadi Ayun Musa ${ }^{2}$ but, in this locality, only continental "Nubian" sandstone occupies the interval between Triassic and Cenomanian. Further south again along the eastern shore of the Dead Sea south of Wadi Zerka Ma'in there are no marine intercalations in the Nubian Sandstone between Cambrian and Cenomanian.

My explanation of these facts is that the shore lines of the Triassic, Jurassic, and, perhaps, Lower Cretaceous seas had a direction approximately parallel to the present Palestine coast and they crossed obliquely what is now the Jordan Valley at, or in the neighbourhood of, the northern end of the Dead Sea. These lines mark the limit of the marine transgressions of these periods and further east-south-eastward continental conditions prevailed over an immense range of time. In 1931 I suggested, ${ }^{2}$

1 Cox, L. R., "Further Notes on the Trans-Jordan Trias," Annals and Mag. of Nat. Hist., Ser. 10, vol. x, 93-113, 1932.

2 Lees, G. M., "Salt. Some Depositional and Deformational Problems," Journ. Inst. Pet. Tech., 1931, ix, p. 267. 
as one possibility, a Triassic age for the salt of Jebel Usdum at the southwest corner of the Dead Sea, basing my idea on a study of the palaeogeography of the region which I illustrated by a map showing shore-lines.

The area at the north-east corner of the Dead Sea is of exceptional geological interest from many points of view and deserves much more detailed study than has been given to it hitherto. I hope that $M$. Avnimelech may be stimulated to undertake it himself. In the interests of accuracy of record I should like to point out that the Yabbok Valley is incorrectly marked on his sketch map as the "Yarmuk R." I can confirm his statement that the fossils described by L. R. Cox in 1925 were from the Yabbok Valley but close to the point of its debouchment into the Jordan Valley. The outcrop of Jurassic extends for some distance south of the Yabbok along the flank of the Jordan Valley, that is, in the direction of the new locality now recorded.

\section{BRITANNIC HoUSE, \\ FINSBURY CIRCUS, \\ LONDON, E.C. 2.}

\section{AN INDICATOR OF WATERFLOW IN CAVES}

SIRs,- The following abstract of a larger paper which I am preparing on the subject of those curious interconnected hollows seen on the walls, roofs, and floors of many caves may be of interest to speleologists.

The pattern often referred to as "honeycomb", "oyster-shell," etc., is termed by some U.S.A. geologists, " flutes." 1 It is also observed in surface streams and rivers, but in the absence of sub-aerial weathering, it is best developed in caverns. I have proposed the term "pocket" to describe these forms and "pocketing" the process, as the American term "flute" and "fluting" is apt to be confused with long groovings (e.g. near waterfalls).

Pocketing is the result of directional waterflow of high velocity causing a complex of vortices under certain conditions. These vortices, helped by the abrasional power of the stream load and in the case of limestone also by solution, tend to scour out asymmetrical pockets with a steep side invariably upstream and a broader surface (usually ending in the apex of a triangle) downstream. Variations in stream velocity and redistribution of the vortices cause overlapping of pockets, etc.

Tubular-sectioned cave passages, pocketed on walls, ceiling and floor, postulate a completely water-filled passage, often under hydrostatic pressure flow. Thus pockets are known to indicate an upgrade flow in some caves. .

The chief interest of pocketing to the speleologist is that it provides a means of plotting the direction of waterflow in dry stream-deserted passages and caverns ; that is if pocketing is present and not obscured by dripstone, etc.

The following rules will help to establish the direction of waterflow which formed the pockets :-

1 Bretz, J. H., "Vadose and Phreatic Features of Limestone Caverns," Journ. Geol., 1 (1942), 675-811. 